Original article

\title{
Degradation of soil cyanide by single and mixed cultures of Pseudomonas stutzeri and Bacillus subtilis
}

\author{
Ogbonnaya Nwokoro and Marie Esther Uju Dibua \\ Industrial Microbiology and Biotechnology Laboratory, Department of Microbiology, University of Nigeria, Nsukka, \\ Nigeria
}

Received in September 2013

CrossChecked in September 2013

Accepted in December 2013

\begin{abstract}
The aim of this investigation was to study whether certain bacteria could be used for cyanide degradation in soil. The bacteria Pseudomonas stutzeri and Bacillus subtilis were selected based on their good growth in a minimal medium containing $0.8 \mathrm{mg} \mathrm{mL}^{-1}$ potassium cyanide $(\mathrm{KCN})$. In this study we tested their ability to reduce cyanide levels in a medium containing $1.5 \mathrm{mg} \mathrm{mL}^{-1}$ of $\mathrm{KCN}$. Although both microorganisms reduced cyanide levels, Pseudomonas stutzeri was the more effective test organism. Later on, the selected cultures were grown, diluted and their various cell concentrations were used individually and in combination to test their ability of cyanide degradation in soil samples collected around a cassava processing mill. Bacillus subtilis caused degradation of soil cyanide from $0.218 \mathrm{mg} \mathrm{g}^{-1}$ soil immediately with an inoculum concentration of $0.1\left(\mathrm{OD}_{600 \mathrm{~mm}}\right)$ to $0.072 \mathrm{mg} \mathrm{g}^{-1}$ soil after 10 days with an inoculum concentration of 0.6 $\left(\mathrm{OD}_{600 \mathrm{~nm}}\right)$ implying a $66.9 \%$ reduction. Pseudomonas stutzeri cell concentration of $0.1\left(\mathrm{OD}_{600 \mathrm{~nm}}\right)$ decreased soil cyanide from $0.218 \mathrm{mg} \mathrm{g}^{-1}$ soil initially to $0.061 \mathrm{mg} \mathrm{g}^{-1}$ soil after 10 days with an inoculum concentration of $0.6\left(\mathrm{OD}_{600 \mathrm{~nm}}\right)(72 \%$ reduction). The mixed culture of the two bacteria produced the best degradation of soil cyanide from $0.218 \mathrm{mg} \mathrm{g}^{-1}$ soil sample with a combined inoculum concentration of $0.1\left(\mathrm{OD}_{600 \mathrm{~nm}}\right)$ initially to $0.025 \mathrm{mg} \mathrm{g}^{-1}$ soil with a combined inoculum concentration of $0.6\left(\mathrm{OD}_{600 \mathrm{~nm}}\right)$ after 10 days incubation resulting in an $88.5 \%$ degradation of soil cyanide. The analysed bacteria displayed high cyanide degradation potential and may be useful for efficient decontamination of cyanide contaminated sites.
\end{abstract}

KEY WORDS: bacterial isolates; biological detoxification of cyanide; cassava processing; environmental pollution; soil microflora

Cyanide is a carbon-nitrogen radical, which may be found in a wide variety of organic and inorganic compounds. Its toxicity to living cells is as a result of three major mechanisms: strong chelation to metals in metallo-enzymes; reaction with keto compounds to form cyanohydrin derivatives of enzyme substrates; and reaction with Schiff-base intermediates during enzymic reactions to form stable nitrile derivatives (1, 2 ). Cyanide is a major inhibitor of the enzyme cytochrome oxidase as well as haemoproteins and other metal-containing oxidases or oxygenases (3).

The risks due to unregulated disposal cyanide from industrial effluents have led to widespread concern (4). Considering its high toxicity, cyanide containing effluents cannot be discharged without being subjected to treatment to reduce their cyanide contents to very low levels ( $<0.1 \mu \mathrm{g}$ of $\mathrm{CN}^{-}$per litre) (5). Environmental hazards associated with cyanide pollution have made biological detoxification of cyanide an attractive alternative to the use of chemical detoxification procedures. Biological detoxification procedures are both cheaper and more environmentally acceptable than chemical methods (6). A wide range of microorganisms have the ability to degrade toxic compounds which enter the environment as a result of pollution and natural activities. Natural soil microflora have been demonstrated to convert cyanide to carbonate and ammonia (7). Some organisms 
resistant to cyanide have been reported to remain active even at concentrations higher than $1 \mathrm{mmol} \mathrm{L}^{-1}$ (8).

The present study focuses on solving an issue of great ecological importance, especially in Nigeria. The processing of cassava (Manihot esculenta) into garri (tapioca), a commonly used food item, involves several operations including peeling, grating, pressing, and fermentation $(9,10)$. These processes are associated with the discharge of large amounts of water, hydrocyanic acid, and organic matter. The cyanide content of cassava plants varies with the plant variety and soil conditions and may range between 75 and $1000 \mathrm{mg} \mathrm{kg}^{-1}$ of $\mathrm{CN}$ and large amounts of natural cyanogenic glycosides found in cassava are released during the production of starch from cassava tubers (11). These cyanogenic glycosides can be enzymatically hydrolysed into cyanide, which is often found in the waste water discharged from cassava processing industries. The release of cyanide from industries worldwide has been estimated to exceed 14 million $\mathrm{kg}$ per year (12). Unused cyanide compounds are released in the effluent coming out from industries causing contamination of the soil as well as water bodies affecting the biogeochemical cycle (13). Cyanide is highly toxic to humans and aquatic organisms (14), which is why cyanide-containing effluents cannot be discharged into the environment without detoxification (15).

Cassava processing waste is improperly disposed in the soil resulting in offensive odours and unsightly scenarios. The deleterious effects of cassava mill effluent on soil can be seen in the high levels of cyanogenic glycosides, biochemical oxygen demand, soluble carbohydrates, and proteins (10). This work reports the inoculation of microorganism cultures to cyanide-contaminated soil with the aim of reducing cyanide levels.

\section{MATERIALS AND METHODS}

\section{Chemicals and reagents}

Potassium cyanide $(\mathrm{KCN})$, Magnesium chloride $\left(\mathrm{MgCl}_{2} \times 2 \mathrm{H}_{2} \mathrm{O}\right.$, Sodium carbonate $\left(\mathrm{Na}_{2} \mathrm{CO}_{3}\right)$, Potassium chloride $(\mathrm{KCl})$, Calcium chloride $\left(\mathrm{CaCl}_{2}\right)$, Ferric sulphate $\left(\mathrm{FeSO}_{4} \times 7 \mathrm{H}_{2} \mathrm{O}\right)$, Magnesium sulphate $\left(\mathrm{MgSO}_{4} \times 7 \mathrm{H}_{2} \mathrm{O}\right)$, Zinc sulphate $\left(\mathrm{ZnSO}_{4}\right)$ were purchased from BDH Chemicals Ltd. (Poole,
England). Sodium dihydrogen phosphate $\left(\mathrm{NaH}_{2} \mathrm{PO}_{4}\right)$, Sodium hydrogen phosphate $\left(\mathrm{Na}_{2} \mathrm{HPO}_{4}\right)$, Potassium hydrogen phosphate $\left(\mathrm{K}_{2} \mathrm{HPO}_{4}\right)$, Sodium chloride $(\mathrm{NaCl})$ were purchased from Sigma-Aldrich Chemie Gmbh (Steinheim, Germany). Copper sulphate $\left(\mathrm{CuSO}_{4} \times 5 \mathrm{H}_{2} \mathrm{O}\right)$, Manganese sulphate $\left(\mathrm{MnSO}_{4} \times 5 \mathrm{H}_{2} \mathrm{O}\right)$ were obtained from Bio-Lab UK Ltd. (Cockspur Street, London). Sodium hydroxide $(\mathrm{NaOH})$ was obtained from Nexill World Chem Chadwell Health (Essex, England), Potassium hydroxide (KOH) from Avondale Laboratories (Banbury, Oxon, England), Picric acid from Qualikems Fine Chemicals PVT. Ltd. (India), Glucose from May and Baker Ltd. (Dagenham, England), and Nutrient agar from Oxoid, Ltd. (UK).

\section{Isolation of bacteria}

Soil samples were collected from a cassava processing mill and $1 \mathrm{~g}$ of soil was added into a conical flask containing $10 \mathrm{~mL}$ of distilled water. The mixture was thoroughly shaken and $1 \mathrm{~mL}$ was serially diluted in normal saline diluents. The dilutions were plated out on Nutrient agar plates and incubated for $24 \mathrm{~h}$ at $35^{\circ} \mathrm{C}$. Pure cultures of the isolates were obtained by streaking onto fresh agar plates and stored on slants at $4{ }^{\circ} \mathrm{C}$.

\section{Screening isolates for their resistance to cyanide}

Test tubes each containing $5 \mathrm{~mL}$ of screening medium (glucose, $2 \%(\mathrm{w} / \mathrm{v})$ in $100 \mathrm{~mL}$ of distilled water) were autoclaved at $12{ }^{\circ} \mathrm{C}$ for 15 minutes. Then, aliquots $(0.1 \mathrm{~mL})$ of $\mathrm{KCN}$ solution $\left(800 \mathrm{mg} \mathrm{L}^{-1}\right)$ sterilised by tyndallisation according to Collins and Lyne (16) was added into each test tube containing the screening medium. Each bacterial isolate was inoculated into each test tube. The test tubes were incubated at room temperature $\left(30 \pm 2{ }^{\circ} \mathrm{C}\right)$ for 2 days. The sensitivity or resistance of each isolate to cyanide was monitored with a Spectrumlab 23A spectrophotometer (Ningbo Tianyu Optoelectronic Co., China) at $600 \mathrm{~nm}$ against a distilled water blank.

\section{Determination of the rates of cyanide degradation by the isolates}

Minimal growth medium $(100 \mathrm{~mL})$ containing $0.5 \%$ glucose and $150 \mathrm{mg}$ of KCN was separately inoculated with each bacterial isolate and incubated in a Gallenkamp orbital incubator (Gallenkamp, England) at $50 \mathrm{~g}$ for $100 \mathrm{~min}$. An un-inoculated control sample was separately prepared. Residual cyanide in the media was monitored at intervals of $20 \mathrm{~min}$. 


\section{Development of inocula}

The medium for the multiplication of Pseudomonas stutzeri had the following composition per litre of distilled water: $1.0 \mathrm{~g}$ of $\mathrm{K}_{2} \mathrm{HPO}_{4} ; 0.2 \mathrm{~g}$ of $\mathrm{MgSO}_{4} \times 7 \mathrm{H}_{2} \mathrm{O}$; $0.01 \mathrm{~g}$ of $\mathrm{CaCl}_{2} ; 0.01 \mathrm{~g}$ of NaCl$; 2.0 \mathrm{mg}$ of $\mathrm{MnSO}_{4}$; $0.2 \mathrm{mg}$ of $\mathrm{CuSO}_{4} \times 5 \mathrm{H}_{2} \mathrm{O} ; 0.2 \mathrm{mg}$ of $\mathrm{ZnSO}_{4} ; 2.0 \mathrm{~g}$ of glucose.

The medium for the multiplication of Bacillus subtilis contained the following per litre of distilled water: $1.0 \mathrm{~g}$ of $\mathrm{KCl} ; 0.2 \mathrm{~g}$ of $\mathrm{MgCl}_{2} \times 2 \mathrm{H}_{2} \mathrm{O} ; 0.25 \mathrm{~g}$ of $\mathrm{CaCl}_{2} \times 2 \mathrm{H}_{2} \mathrm{O} ; 5.0 \mathrm{mg} \mathrm{FeSO}{ }_{4} \times 7 \mathrm{H}_{2} \mathrm{O} ; 1.0 \mathrm{mg}$ of $\mathrm{MnSO}_{4} \times 5 \mathrm{H}_{2} \mathrm{O} ; 5.26 \mathrm{~g}$ of $\mathrm{Na}_{2} \mathrm{HPO}_{4} ; 5.4 \mathrm{~g}$ of $\mathrm{Na}_{2} \mathrm{HPO}_{4}$.

The single inocula of both bacterial cultures were incubated in a Gallenkamp orbital incubator (Gallenkamp, England) for $24 \mathrm{~h}$ and diluted with sterile distilled water to optical densities of 0.1-0.6 measured in a Spectrumlab 23A spectrophotometer (Ningbo Tianyu Optoelectronic Co., China) at $600 \mathrm{~nm}$. Mixed culture inocula (1:1 ratio) was similarly grown, reduced to $500 \mathrm{~mL}$ each, combined and diluted with sterile distilled water to optical densities of 0.1-0.6 measured at $600 \mathrm{~nm}$.

\section{Sampling site}

This experiment was conducted in the dry season of 2013. A total of 18 plots of land (located at Beach Junction, Nsukka, Nigeria) each measuring 30x30 cm was mapped out around a cassava processing mill. The plots were each separately inoculated with bacterial cultures. Soil samples (10 g each) starting from the surface down to $5 \mathrm{~cm}$ depth were collected from different locations of the inoculated mapped plot at intervals of 2 days. Cyanide levels were determined by a modification of the alkaline picric acid method by Williams and Edwards (17) as follows: various quantities of standard $\left(50,100,150\right.$, and $\left.200 \mu \mathrm{g} \mathrm{mL}^{-1}\right)$ $\mathrm{KCN}$ medium were added into tubes with $2 \mathrm{~mL}$ of $2 \%$ $\mathrm{KOH}$ and $1 \mathrm{~mL}$ of picric acid: $\mathrm{Na}_{2} \mathrm{CO}_{3}: \mathrm{H}_{2} \mathrm{O}(1: 5: 200$ $\mathrm{v} / \mathrm{w} / \mathrm{v})$. The tubes were incubated for $10 \mathrm{~min}$ in a $37^{\circ} \mathrm{C}$ water bath, cooled for $20 \mathrm{~min}$ in a refrigerator and read in a Spectrum lab 23A spectrophotometer (Ningbo Tianyu Optoelectronic Co., China) at $510 \mathrm{~nm}$. The readings were used to draw a standard curve for $\mu \mathrm{g} \mathrm{mL}{ }^{-1}$ of $\mathrm{KCN}$ against absorbance.

\section{RESULTS AND DISCUSSION}

A total of 32 bacterial isolates were recovered from the soil. These bacteria were tested for their ability to tolerate high concentrations of cyanide. Two isolates, designated as CBD 10 and CBD 26, which gave the best growth of 0.66 and $0.68\left(\mathrm{OD}_{600 \mathrm{~mm}}\right)$, respectively, in the high cyanide medium, were selected, and used for further investigation. They were identified as Bacillus subtilis and Pseudomonas stutzeri on the basis of morphological, biochemical, and physiological characteristics as described in the literature $(18,19)$.

The degradation of cyanide (added in the growth medium at a concentration of $1.5 \mathrm{mg} \mathrm{mL}^{-1}$ ) by each pure culture is shown in Figure 1. The fastest rate of

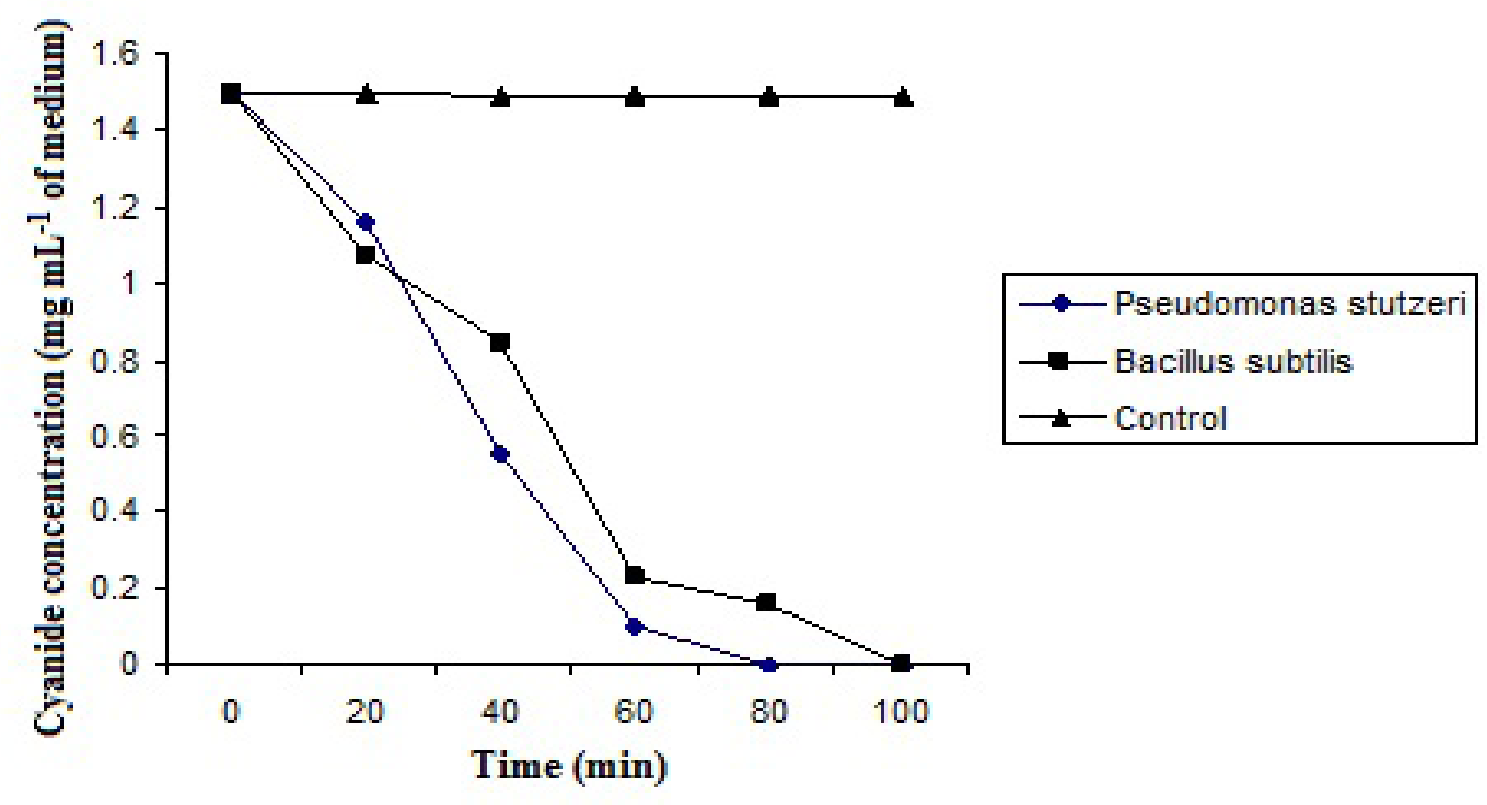

Figure 1 Degradation of cyanide by cultures of Pseudomonas stutzeri and Bacillus subtilis 
cyanide degradation was observed with a culture of Pseudomonas stutzeri where cyanide was not detected after 80 min. However, in the medium containing Bacillus subtilis as the test bacterium, cyanide remained at a concentration of $0.16 \mathrm{mg} \mathrm{mL}^{-1}$. Cyanide content of the control sample remained unchanged after $100 \mathrm{~min}$.

We then proceeded by applying the inocula of the two bacteria to the soil samples. When Bacillus subtilis was used as the test organism, the soil cyanide concentration decreased from $0.218 \mathrm{mg} \mathrm{g}^{-1}$ soil initially with an inoculum concentration of 0.1 $\left(\mathrm{OD}_{600 \mathrm{~mm}}\right)$ to $0.072 \mathrm{mg} \mathrm{g}^{-1}$ soil after 10 days with an inoculum concentration of $0.6\left(\mathrm{OD}_{600 \mathrm{~nm}}\right)$, implying a $66.9 \%$ reduction of soil cyanide (Figure 2).
Inoculation of soil with a cell concentration of 0.1 $\left(\mathrm{OD}_{600 \mathrm{~nm}}\right)$ of Pseudomonas stutzeri caused a decrease in soil cyanide from $0.218 \mathrm{mg} \mathrm{g}^{-1}$ soil initially to $0.061 \mathrm{mg} \mathrm{g}^{-1}$ soil after 10 days with an inoculum concentration of $0.6\left(\mathrm{OD}_{600 \mathrm{~mm}}\right)$, implying a $72 \%$ reduction of soil cyanide (Figure 3). Mixed culture inocula of the two bacteria produced the best reduction of soil cyanide concentration from $0.218 \mathrm{mg} \mathrm{g}^{-1}$ soil sample with a combined inoculum cell concentration of $0.1\left(\mathrm{OD}_{600 \mathrm{~mm}}\right)$ initially to $0.025 \mathrm{mg} \mathrm{g}^{-1}$ soil with a combined cell concentration of $0.6\left(\mathrm{OD}_{600 \mathrm{~nm}}\right)$ after 10 days of incubation, which lead to a $88.5 \%$ reduction of soil cyanide (Figure 4).

This high percentage of cyanide degradation, as observed when using the mix of the two studied

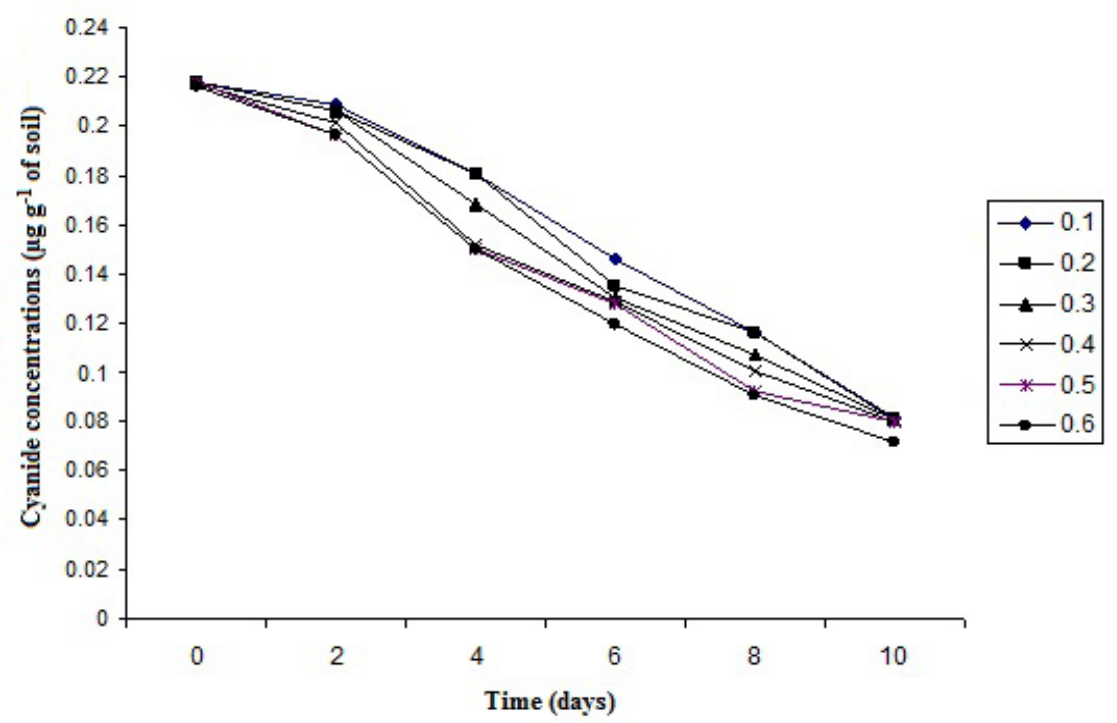

Figure 2 Degradation of soil cyanide by various inoculum concentrations $\left(O D_{600 n m}\right)$ of Bacillus subtilis

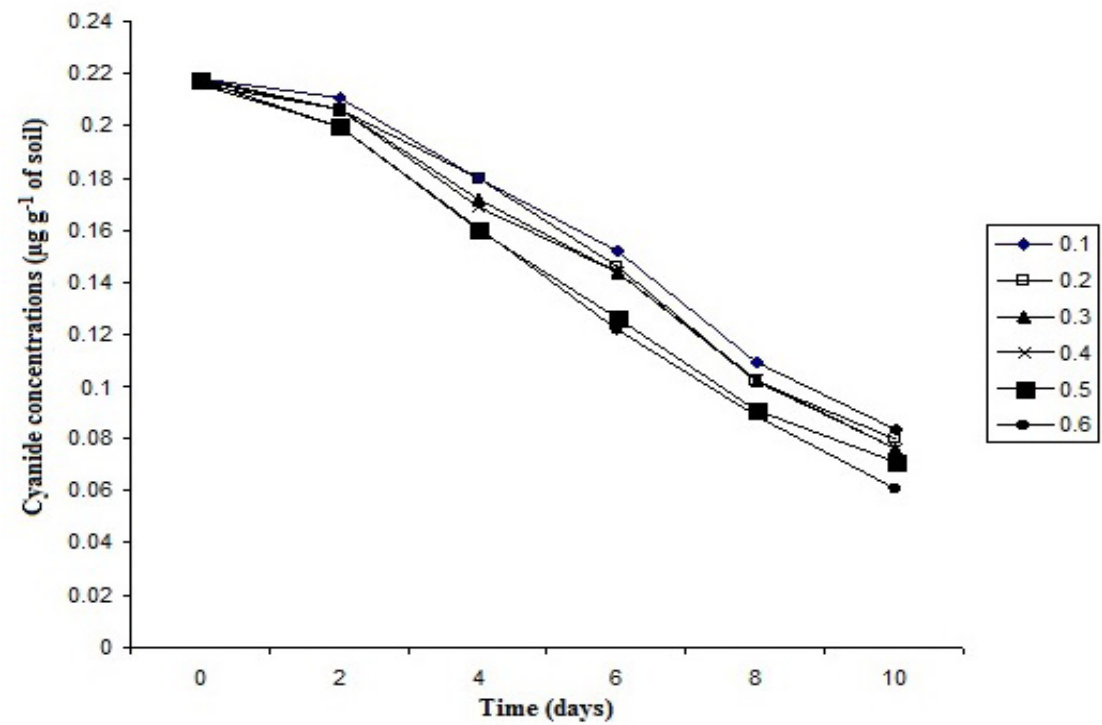

Figure 3 Degradation of soil cyanide by various inoculum $\left(O D_{600 n m}\right)$ concentrations of Pseudomonas stutzeri 


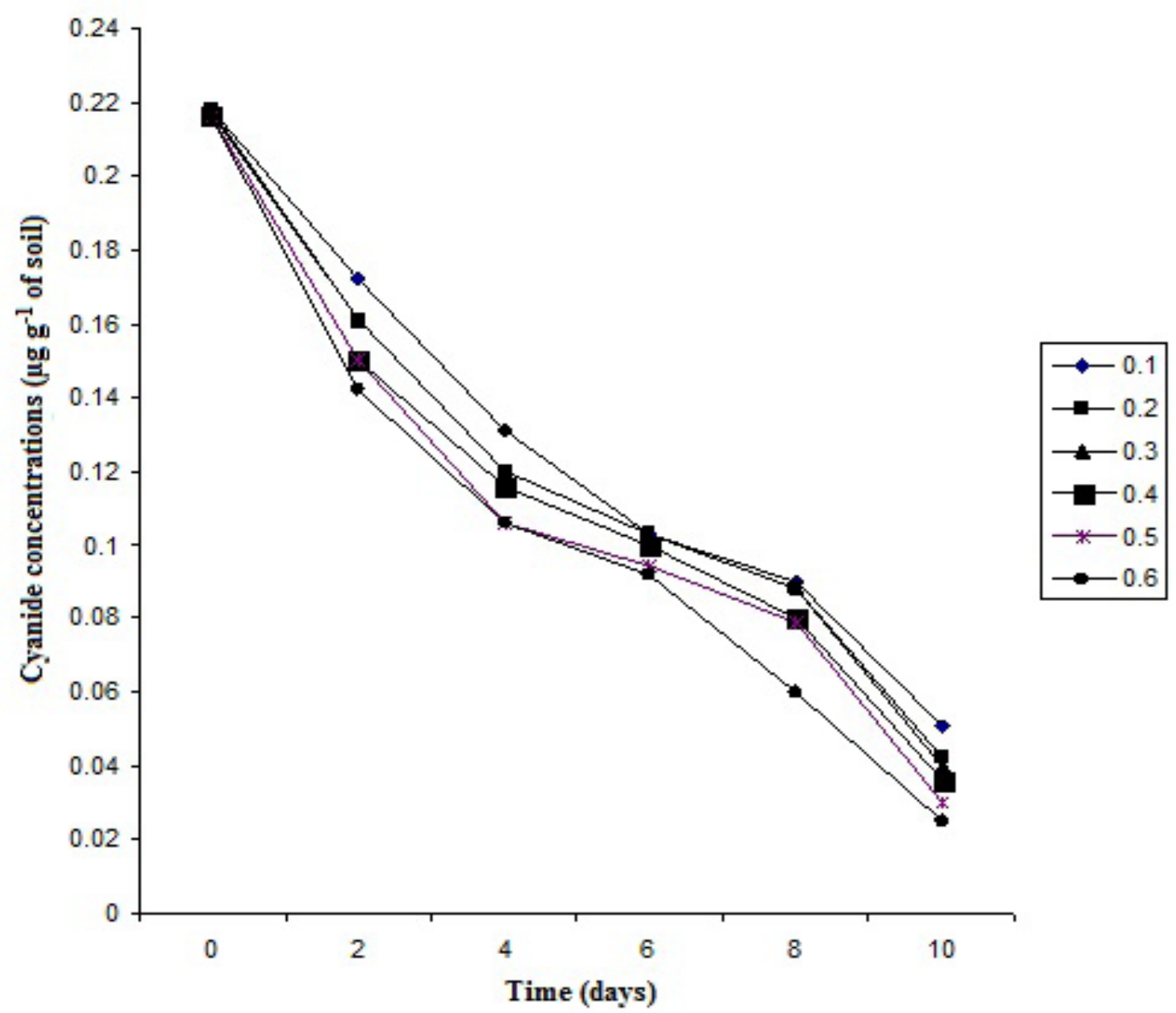

Figure 4 Degradation of soil cyanide by various inoculum $\left(O D_{600 n m}\right)$ concentrations of mixed cultures of Bacillus subtilis and Pseudomonas stutzeri

bacteria, can certainly be deemed as the main finding of this study. Using these organisms by themselves caused only a partial reduction of soil cyanide. The successful degradation as seen in this investigation may have been due to specific enzyme systems inherent to Pseudomonas stutzeri and Bacillus subtilis. As known, microorganisms possess various enzymes capable of converting cyanide into compounds that may serve as carbon and nitrogen substrates. Such enzymes include formamide hydrolase (EC 4.2.1.66), L-3- cyano-alanine synthase (EC 4.4.19) and thiosulphate sulphur transferase (EC 2.8.1.1) (20). Pseudomonas and Bacillus species have previously been reported as efficient cyanide-degrading bacteria $(21,22)$. Both species are capable of growth in cyanide as the sole nitrogen source $(23,24)$. Bacillus species have been reported to biodegrade cyanide to non-toxic end-products by using cyanide as a nitrogen source $(25,26)$. Castric and Conn (27) reported the metabolism of cyanide by Bacillus and proposed the presence of a metabolic pathway involving the condensation of serine with cyanide to form beta- cyanoalanine followed by the hydrolysis of the latter to asparagine and then to aspartic acid. Growth of Pseudomonas in a cyanide medium requires that cyanide be enzymatically converted to ammonia which is then readily assimilated into cellular nitrogen $(2,28)$. Co-culturing microorganisms in cyanide contaminated soils have also been previously reported as an efficient method of controlling environmental pollution $(29,30)$. That is why can ascertain that the results of this study speak in favour of using bacterial inocula for this purpose.

\section{CONCLUSION}

The results of the present investigation suggest that the co-cultivation of Pseudomonas stutzeri and Bacillus subtilis may ensure more efficient cyanide degradation in soil contaminated by cassava processing. However, further work on the kinetic properties of these microorganisms and the mechanisms of soil cyanide degradation by co-cultivation of 
microorganisms in other polluted environments is recommended.

\section{REFERENCES}

1. Solomonson LP. Cyanide as a metabolic inhibitor. In: Vennesland B, Conn EE, Knowles CJ, Westley J, Wissing F, editors. Cyanide in biology. New York (NY): Academic Press; 1981. p. 11-28.

2. Knowles CJ. Cyanide utilization and degradation by microorganisms. CIBA - Found Symp 1988;140:3-15. PMID: 3073060

3. Knowles CJ. Microorganisms and cyanide. Bacteriol Rev 1976;40:652-80. PMCID: PMC413975

4. Yu XZ, Peng XY, Wang GL. Photo induced dissociation of ferri and ferro cyanide in hydroponic solutions. Intl J Environ Sci Technol 2011;8:853-62. doi: 10.1007/BF03326268

5. Smith A, Mudder TI. The Chemistry and Treatment of Cyanidation Wastes. London: Mining Journal Books Ltd; 1991.

6. Meyers PR, Rawlings DE, Woods DR, Lindsey GG. Isolation and characterization of a cyanide dihydratase from Bacillus pumilus C1. J Bacteriol 1993;175:6105-12. PMCID: PMC206703

7. Strobel GA. Cyanide utilization in soil. Soil Sci 1967;103:299302.

8. Chena SC, Liu JK. The respiratory responses to cyanide of a cyanide-resistant Klebsiella oxytoca bacterial strain. FEMS Microbiol Lett 1999;175:37-43. doi: 10.1111/j.1574-6968.1999.tb13599.x

9. Ubalua AO. Cassava wastes: treatment options and value addition alternatives. Afr J Biotechnol 2007;6:2065-73.

10. Okechi RN, Ihejirika CE, Chiegboka NA, Ibe IJ. Evaluation of the effects of cassava mill effluent on the microbial populations and physicochemical parameters at different soil depths. Int J Biosci 2012;2:139-45.

11. Kaewkannetra P, Imai T, Garcia-Garcia FJ, Chiu TY. Cyanide removal from cassava mill waste water using Azotobacter vinelandii TISTR 1094 with mixed microorganisms in activated sludge treatment system. J Harzard Mater 2009;172:224-8. doi: 10.1016/j.jhazmat.2009.06.162

12. Naveena D, Majumder CB, Mondal P, Shubha D. Biological treatment of cyanide containing waste water. Res J Chem Sci 2011;1:15-21.

13. Parmar P, Soni A, Vyas K, Desai PV. Isolation and characterization of cyanide degrading bacterial strains from contaminated soil. Int J Environ Sci 2012;2:2006-14. doi: 10.6088/ijes.00202030084

14. Dursun AY, Aksu Z. Biodegradation kinetics of ferrous(II) cyanide complex ions by immobilized Pseudomonas fluorescens in a packed bed column reactor. Process Biochem 2000;35:615-22. doi: 10.1016/S0032-9592(99)00110-7
15. Dash RR, Balomajumder C, Kumar A. Cyanide removal by combined adsorption and biodegradation processs. Iran $\mathrm{J}$ Environ Health Sci Eng 2006;3:91-6.

16. Collins CH, Lyne PM. Microbiological Methods. London: Butherworths; 1970.

17. Willians HJ, Edwards TG. Estimation of cyanide with alcaline picrate. J Sci Food Agric 1980;31:15-22. doi: 10.1002/ jsfa.2740310104

18. Skinner FA, Lovelock DW. Identification Methods for Microbiologists. $2^{\text {nd }}$ ed. London: Academic Press; 1979.

19. Holt JG, Krieg NR, Sneath PHA, Staley JT, Williams ST. Bergey's Manual of Determinative Bacteriology. $9^{\text {th }}$ ed. Baltimore: Williams and Wilkins; 1994.

20. Ingvorsen K, Højer-Pedersen B, Godtfredsen SE. Novel cyanide hydrolyzing enzyme from Alcaligenes xylosoxidans subsp. denitrificans. Appl Environ Microbiol 1991;57:17839. PMID: 1872607

21. Ebbs S. Biological degradation of cyanide compounds. Curr Opin Biotechnol 2004;15:231-6. PMID: 15193331

22. Huertas MJ, Saez LP, Roldan MD, Luque-Almagro VM, Martinez-Luque M, Blasco R, Moreno-Vivian C, Castillo F, Garcia-Garcia I. Alkaline cyanide degradation by Pseudomonas pseudoalcaligenes CECT5344 in a batch reactor: Influence of pH. J Harzard Mater 2010;179:72-8. doi: 10.1016/j.jhazmat.2010.02.059

23. Harris R, Knowles CJ. Isolation and growth of a Pseudomonas specie that utilizes cyanide as a source of nitrogen. J Gen Microbiol 1983;129:1005-11. doi: 10.1099/00221287-1294-1005

24. Luque-Almagro VM, Blasco R, Huertas MJ, Martínez-Luque M, Moreno-Vivián C, Castillo F, Roldán MD. Alkaline cyanide biodegradation by Pseudomonas pseudoakaligenes CECT5344. Biochem Soc Trans 2005;33:168-9. PMID: 15667296

25. Sirianuntapiboon S, Chuamkaew C. Packed cage rotating biological contractor system for treatment of cyanide waste water. Bioresour Technol 2007;98:266-72. PMID: 16530409

26. Skowronski B, Strobel GA. Cyanide resistance and cyanide utilization by a strain of Bacillus pumilus. Canad J Microbiol 1969;15:93-8. doi: 10.1139/m69-014

27. Castric PA, Conn EE. Formation of -cyanoalanine by O-acetylserine sulfhydrylase. J Bacteriol 1971;108:132-6. PMID: 5001194

28. Kunz DA, Wang C, Chen J. Alternative routes of enzymic cyanide metabolism in Pseudomonas fluorescens NCIMB 11764. Microobiology 1994;140:1705-12. PMID: 8075806

29. Barclay M, Hart A, Knowles CJ, Meeussen JCL, Tett VA. Biodegradation of metal cyanides by mixed and pure cultures of fungi. Enzyme Microbial Technol 1998;22:223-31. doi: 10.1016/S0141-0229(97)00171-3

30. Ezzi MI, Lynch JM. Biodegradation of cyanide by Trichoderma spp. and Fusarium spp. Enzyme Microbial Technol. 2005;36:849-54. doi: 10.1016/j. enzmictec.2004.03.030 


\section{Sažetak}

\section{Razgradnja cijanida u tlu s pomoću pojedinačnih i miješanih kultura bakterija Pseudomonas stutzeri i Bacillus subtilis}

Bakterije Pseudomonas stutzeri i Bacillus subtilis odabrane su na temelju zamjetnog rasta u minimalnom mediju s $0,8 \mathrm{mg} \mathrm{mL}^{-1}$ kalijeva cijanida (KCN). Tijekom ovog istraživanja ispitivana je njihova sposobnost reduciranja razina cijanida u mediju s $1,5 \mathrm{mg} \mathrm{mL}^{-1} \mathrm{KCN}$. Iako su obje bakterije smanjile koncentraciju cijanida, Pseudomonas stutzeri bila je učinkovitija. Kasnije, odabrane kulture su uzgojene, razrijeđene i u različitim koncentracijama korištene pojedinačno ili u mješavini za ispitivanje njihove učinkovitosti pri razgradnji cijanida u uzorcima tla prikupljenim u blizini mlina za preradu manioke. Bacillus subtilis je uzrokovala razgradnju cijanida od $0,218 \mathrm{mg} \mathrm{g}^{-1}$ na početku pri koncentraciji inokuluma od $0,1\left(\mathrm{OD}_{600 \mathrm{~nm}}\right)$ do $0,072 \mathrm{mg} \mathrm{g}^{-1}$ tla nakon deset dana pri koncentraciji od $0,6\left(\mathrm{OD}_{600 \mathrm{~nm}}\right)$, što je smanjenje od $66,9 \%$. Stanična koncentracija Pseudomonas stutzeri od $0,1\left(\mathrm{OD}_{600 \mathrm{~nm}}\right)$ smanjila je razinu cijanida u tlu s $0,218 \mathrm{mg} \mathrm{g}^{-1} \mathrm{na}$ početku do $0,061 \mathrm{mg} \mathrm{g}^{-1}$ nakon deset dana pri koncentraciji od $0,6\left(\mathrm{OD}_{600 \mathrm{~nm}}\right)$, što je smanjenje od $72 \%$. Mješavina dviju bakterija dala je najbolju razgradnju; od $0,218 \mathrm{mg} \mathrm{g}^{-1}$ pri miješanoj koncentraciji inokuluma od $0,1\left(\mathrm{OD}_{600 \mathrm{~nm}}\right)$ na početku do $0,025 \mathrm{mg} \mathrm{g}^{-1}$ tla nakon 10 dana pri $0,6\left(\mathrm{OD}_{600 \mathrm{~nm}}\right)$, što je rezultiralo smanjenjem cijanida od $88,5 \%$. Analizirane bakterije pokazale su visoki potencijal za razgradnju cijanida i mogle bi biti učinkovite za dekontaminaciju cijanidom zagađenih lokacija.

KLJUČNE RIJEČI: bakterijski izolati; biološka detoksifikacija cijanida; mikroorganizmi u tlu; prerada manioke; zagađenje okoliša

\section{CORRESPONDING AUTHOR:}

\section{Ogbonnaya Nwokoro}

Industrial Microbiology and Biotechnology Laboratory, Department of Microbiology, University of Nigeria, Nsukka, Nigeria

E-mail:ogb883@yahoo.com 